\title{
A MECHANISM FOR EXCITATION AND INHIBITION OF THE MAUTHNER'S CELLS IN TELEOST: \\ A HISTOLOGICAL AND NEURO- PHYSIOLOGICAL STUDY
}

\author{
ERNEST RETZLAFF 1,2 \\ Department of Physiology, University of Michigan, Ann Arbor, Michigan and \\ Department of Psychiatry, University of Illinois, \\ Chicago, Illinois \\ EIGHT FIGURES \\ INTRODUCTION
}

The site of synaptic endings of afferent fibers on motoneurons or inter-neurons in the central nervous system has been considered by many investigators to be one of the important factors in determining whether an impulse will excite or inhibit. The above considerations have led to the formulation of the concept of polar function of the neuron or some variation of it.

The importance of axon collaterals and of other types of interneuronal relationships in nervous integration was emphasized by Brown ('14), Gesell ('40a,b), Sherrington ('40), Renshaw ('41), Gesell et al. ('54), Holmgren and Merton ('54) and Eccles et al. ('54). The existence of axon collaterals was reported as early as 1891 by Köllicker, by Lenhossek in 1893 and again by Ramón y Cajal in 1911. The more recent work of Coghill ('34), Bodian ('37, '52) and Retzlaff ('54a,b, '55) has shown not only the origin of these axon branchings but their destination.

${ }^{1}$ This work was partially supported by a grant from the Public Health Service, National Institute of Neurological Disease and Blindness.

${ }^{2}$ Present address: Columbus Receiving Hospital, Research Division, Department of Psychiatry, Ohio State University, Columbus 10, Ohio. 
This report is concerned with the structural and functional relationships of the VIIIth nerve afferents to the bilaterally situated Mauthner's cells in the medulla of fishes.

\section{METHODS}

The brains of the bullheads used for histological study were processed by the freeze-dehydration method, ${ }^{3}$ then paraffin embedded, serially sectioned and stained with protargol. The details of this method have been reported previously by this author ('55). All histological observations and photomicrographs were made using a phase-contrast microscope.

The fish used in the physiological experiments were cooled in aerated ice water $\left(5^{\circ} \mathrm{C}\right.$.) for about an hour, or until they showed little sensitivity to moderate electrical shocks applied to the skin. This method avoided the interfering effects of anesthetic drugs.

By carefully removing the skin and bone covering the midbrain and medulla, the VIIIth nerves were exposed. Particular care was taken to avoid injury to the brain or the afferent fibers. Bleeding was minimal because of the vasoconstrictor action of the cold.

The fish was secured to a lucite platform by means of strings tied to the pectoral spines and the tail. The preparation was then lowered into a lucite container partly filled with ice and water so that the gills were just immersed. Air was bubbled into the mouth throughout the entire experiment. Unless gill movements were evident at all times, the animal was discarded.

Glass silver-silver chloride salt-bridge recording electrodes made of Kimble N51-A glass tubing drawn to a diameter of $10 \mu$ were inserted into the spinal cord to record the Mauthner's axon activity. By positioning these electrodes near the emergence of the spinal roots of the same segment, it was possible to determine the points of optimal activity with little difficulty.

\footnotetext{
${ }^{3}$ A freeze-dryer of design for operation on the prineipal used in this study is available from the F. J. Stokes Machine Company, Philadelphia 20, Pa.
} 
Bipolar stimulating electrodes of chloridized silver wire were positioned around the VIIIth nerve roots on each side at the point of their entry into the medulla. In some experiments, these nerve root bundles were divided until only a few or even a single fiber remained. This made it possible to determine which afferents were most effective in producing the desired activity in the fish.

In all experiments, the effect of stimulation was observed before intramuscular administration of $d$-tubocurarine $(0.1$ $1.0 \mathrm{~cm}^{3}$ of $1 \%$ solution). It was found that several injections of about $0.1 \mathrm{~cm}^{3}$ of this drug at intervals of 5 minutes aided in determining the correct amount required for each fish.

The activity at the pairs of electrodes was recorded on moving film, using two direct-coupled amplifiers in conjunction with a dual beam oscilloscope. Stimulation was accomplished by means of synchronized square-wave generators each with an isolation transformer unit.

\section{HISTOLOGICAL OBSERVATIONS}

The two Mauthner's cells in the medulla oblongata of teleosts are highly specialized reticular cells lying in the floor of the ventricle. Each cell has a single lateral dendrite extending toward the entering root of the VIIIth nerve, and one or more ventral dendrites that extend almost to the ventral surface of the medulla. The numerous synaptic endings covering the surfaces of the dendrites, the cell body and the axon hillock region are the terminations of the direct afferents (VIIIth nerve) and the indirect afferents from the vestibular, the lateral line and other systems. The large axon of each of the two Mauthner's cells extends to the most caudal segments and activates the motoneurons supplying the body musculature of the fish. Studies on the morphology of these cells have been presented by Bartelmez ('15), Bartelmez and Hoerr ('33), Coghill ('34), and Bodian ('37, '52). Ariëns Kappers, Huber and Crosby ('36) presented an excellent discussion of the phylogenetic development of the reticular cell system in vertebrates. 


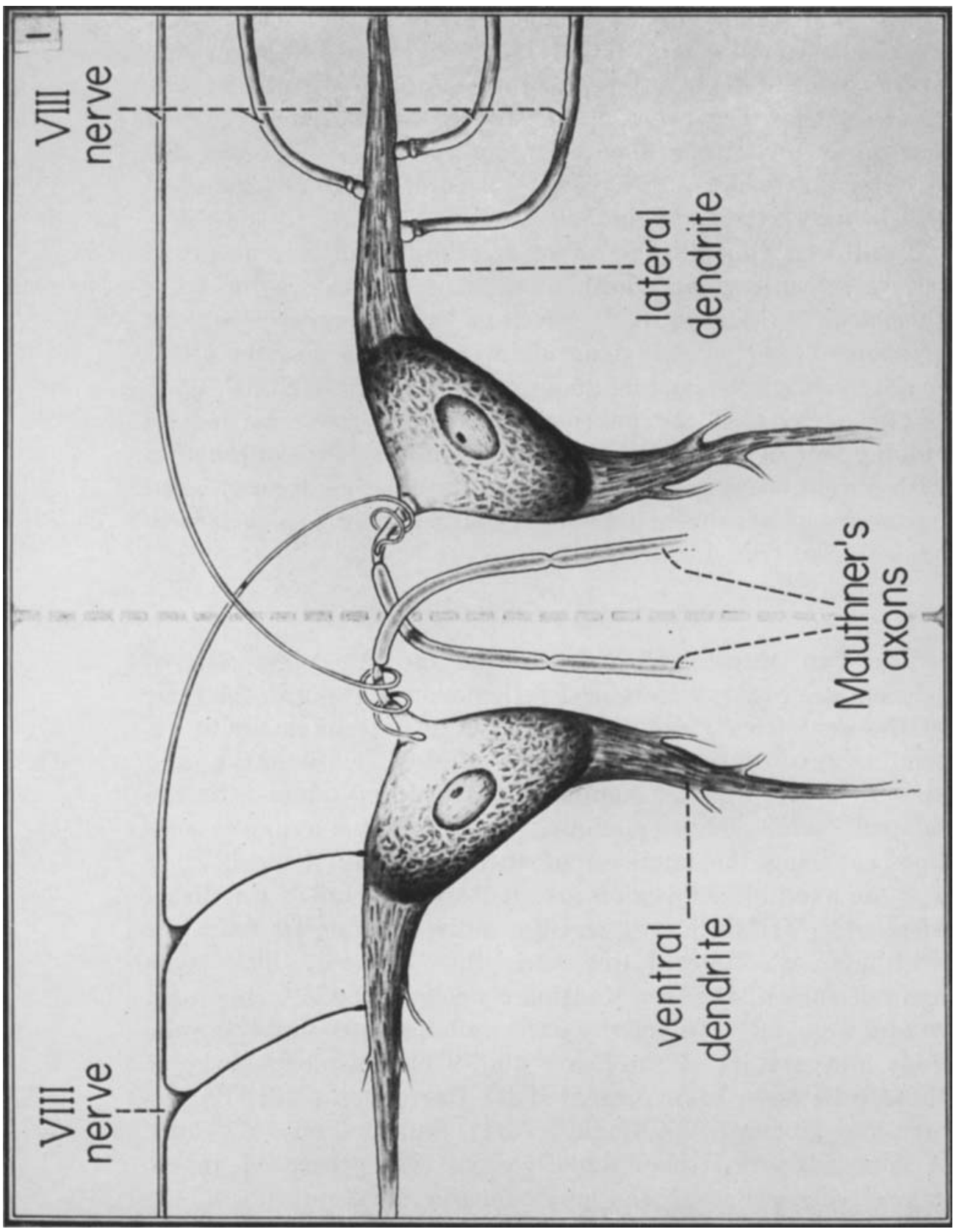

.

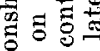

苟害

중 计

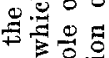

舟它

造造

का

का

更

부볍ㅁㅇㅝ

舫

串要

응 욜

政

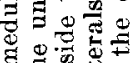

$\neq$ 要类

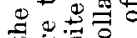

$\pi$ \%

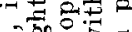

可然

os

के

\#0.E

. $\bar{F}$

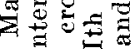

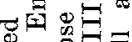

象>

형둥

\&灾苋

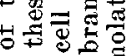

푸요

$\exists$ 和要

无事

क्षित

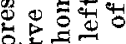

焉害

正要

苞它范

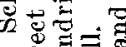

훙

-

$\dot{0} \overrightarrow{0}$ 出产要 
There are three types of direct VIIIth nerve-Mauthner's cell relations. The first two, previously discussed by Retzlaff ('54b) are the unbranched afferents which end as large myelinated clubs on the distal portion of the lateral dendrite of the homolateral Mauthner's cell, and the unbranched decussating afferents which end as non-myelinated clubs on or near the axon hillock of the contralateral Mauthner's neuron. There is a third type of direct VIIIth nerve connection with the two Mauthner's cells (fig. 1). This type is made by afferents that branch in such a way that the collaterals of a single fiber terminate on the proximal portion of the lateral dendrite and on the cell body of the homolateral cell (fig. 2). The stem fiber then crosses to the opposite side of the medulla, where it gives off terminal collaterals which form a part of the coarse fiber portion of the axon cap to end on or near the axon hillock of the Mauthner's cell contralateral to its side of origin (fig. 3). The endings of these branched fibers are elongated bulb-like enlargements which differ from the non-myelinated synaptic clubs of the unbranched VIIIth nerve fibers. Those seen in figure 2 are the synaptic bulbs of fibers ending on the cell body of the Mauthner's cell on the same side as their origin. The termination of the contralaterally arising VIIIth nerve fiber contacts the proximal portion of the Mauthner's axon as shown in figure 3.

It is evident that the synaptic endings of the three types of direct VIIIth nerve afferents are distributed to specific areas on the Mauthner's cells. The giant myelinated clubs (fig. 4) are restricted to the distal tip of the lateral dendrite of the homolateral cell. The non-myelinated clubs of the decussating fibers end only on the axon pole of the contralateral cell. The synaptic bulbs of the branched fibers end on the proximal portion of the lateral dendrite and the cell body of the Mauthner's cell on the same side as their origin and on or near the axon hillock of the Mauthner's cell on the opposite side. The indirect VIIIth nerve-Mauthner's cell connections by way of the vestibular nuclei also have a 

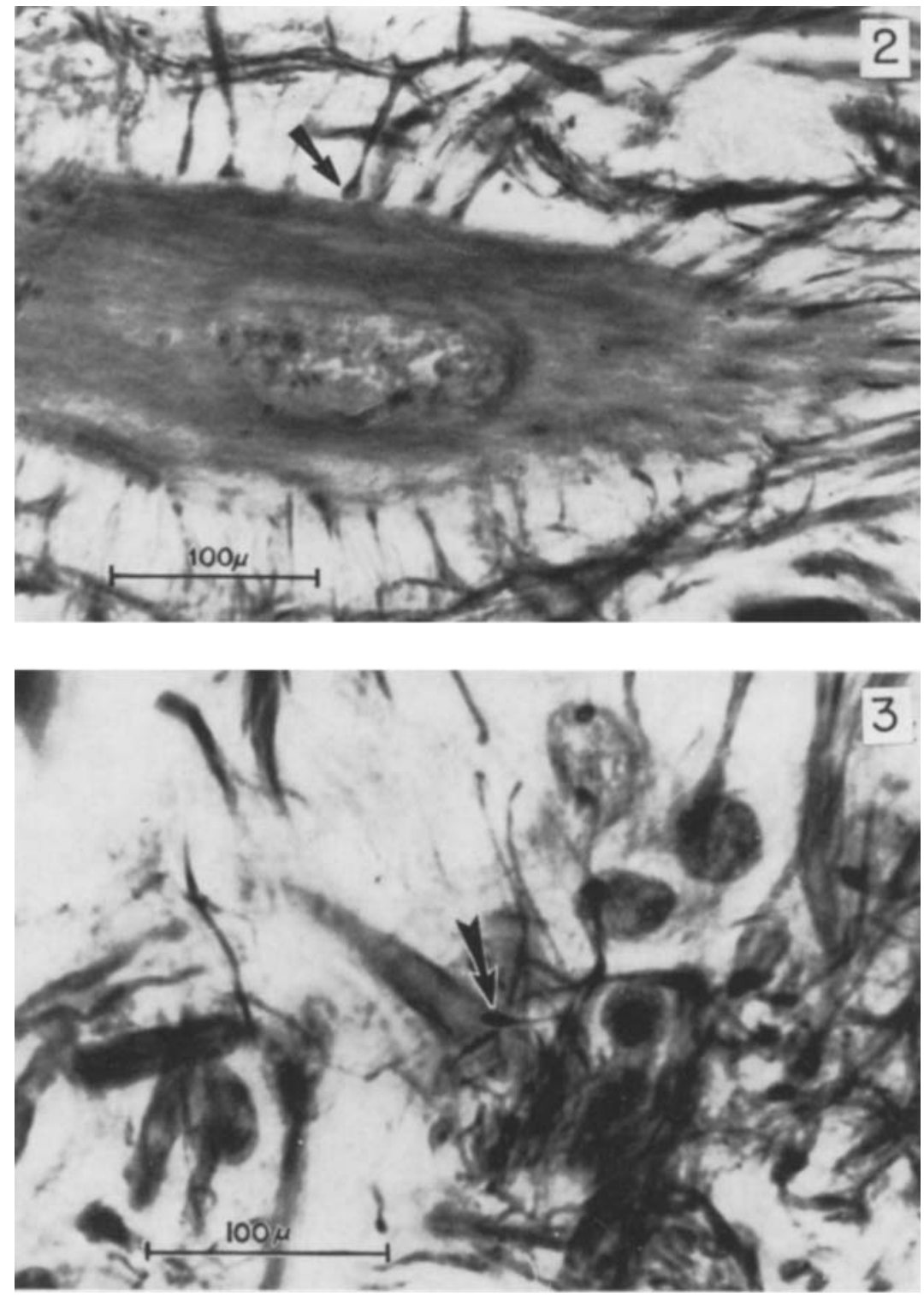

Fig. 2 Photomicrograph showing an axon collateral of a direct VIIIth nerve afferant ending as a synaptic bulb (arrow) on the cell body of the homolateral Mauthner's cell in the bullhead. The other large synaptic bulbs seen on the upper border of the cell are also endings of these branched fibers but they lie at a slightly different level of focus. Note the other types of synaptic endings on the lower border of the cell. (Freeze-dehydration, protargol stain, oil immersion photomicrograph.)

Fig. 3 Photomicrograph showing a terminal collateral of a branched VIIIth nerve afferent ending as a synaptic bulb (arrow) on the surface of the proximal portion of the Mauthner's axon in the bullhead. This VIIIth nerve fiber can be traced in serial section from its origin on the opposite side of the brain to the place this picture was taken. (Freeze-dehydration, protargol stain, oil immersion photomicrograph.) 
definite pattern of synaptic endings on the paired Mauthner's cells (Retzlaff, '54b). Some of the axons from the vestibular nuclei end on the ventral dendrite and the cell body of the homolateral cell and others end on the axon pole of the contralateral cell.

\section{RESULTS}

Experiments done to determine the effects of VIIIth nerve stimulation on the activity of the two Mauthner's cells as demonstrated either by the observed responses which were characterized by a rapid flexion of the tail, by electromyograms in the non-curarized fish, or by recording the evoked potentials from the two Mauthner's axons after the fish had been curarized. In all examples cited, the observed responses are described and the electrical activity is illustrated in the appropriate figures.

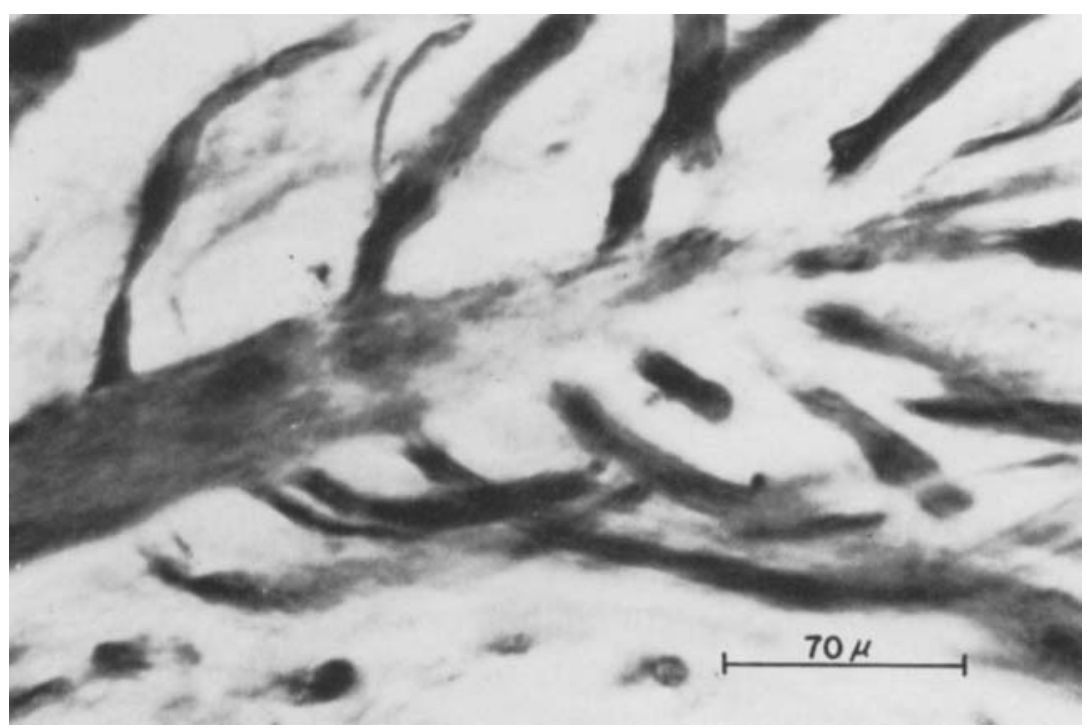

Fig. 4 Photomicrograph of myelinated club-like synaptic endings of the direct unbranched VIIIth nerve fibers which end on the distal tip of the lateral dendrite of the homolateral Mauthner's cell in the bullhead. Note the intimate contact of the synaptic ending with the dendrite at the upper left. (Freeze-dehydration protargol stain, oil immersion photomicrograph.) 


\section{Unilateral and alternate stimulation}

The result of single threshold shocks of short duration ( 0.2 msec.) given to the VIIIth nerve roots on either side was a rapid flexion of the tail in the same direction as the applied stimulus. An electromyogram of this activity is illustrated in figure 5. This same pattern of response oc-

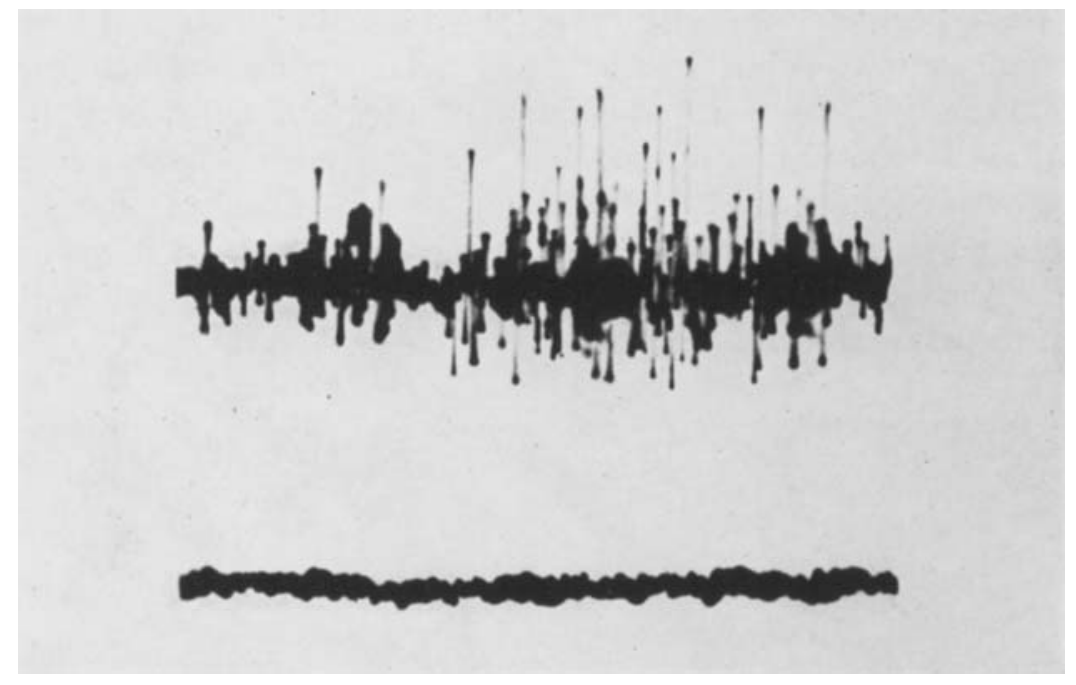

Fig. 5 Bilateral electromyogram of tail muscle activity resulting from uni. lateral stimulation of the VIIIth nerve afferents. The upper beam shows the response on the same side as the applied stimulus while the lower beam indicates the inactivity of the unstimulated side. The stimulus was applied at the start of the record.

curred irrespective of the position of the tail prior to the application of the stimulus.

Alternate or random stimulation of both VIIIth nerve roots also caused the fish to move its tail in a direction toward the side of each applied stimulus. There was a definite one-to-one stimulus-response pattern evident in all cases. Recordings of the evoked potentials from the two Mauthner's axons at the same segmental level of the spinal cord show this same type of stimulus-response relationship (fig. 6). The high axonal 
conduction rate of $35-40 \mathrm{~m} / \mathrm{sec}$. (Graham and $\mathrm{O}^{\prime}$ Leary, ' 41 ; Tasaki et al., '54), even when the fish was cooled to $5^{\circ} \mathrm{C}$., made it possible to distinguish the discharge of these neurons from those of the other efferent systems.

It is evident in the record shown in figure 6 that stimulation of the VIIIth nerve roots of either side resulted in the excitation of the homolateral Mauthner's cell, but it was not possible by this method to determine whether the absence of excitation of the contralateral cell was the result of an active inhibitory process or for some other reason. However,
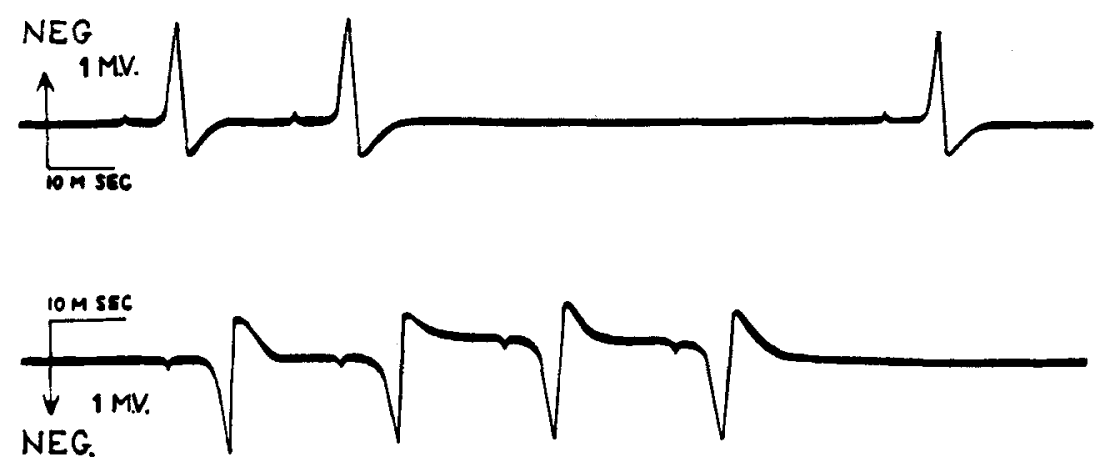

Fig. 6 Dual recording from the Mauthner's axons to show the propagated impulses produced by a random sequence of bilateral VIIIth nerve stimulation in the curarized bullhead (see text).

it should be noted that there was an increase in the latent period on one side when the other had just responded to a threshold stimulus. The upper beam of the recording seen in figure 6 displayed a latent period of about $6 \mathrm{msec}$. which agrees with the calculated axonal conduction rate allowing 1 msec. for the synaptic delay. In contrast, the total response time of the other side (lower beam) was increased some 2 msec. over the first. When only the side which had this increased latent period was stimulated, the latency decreased to the expected time of $6 \mathrm{msec}$. The significance of this change in latency will be discussed later. 


\section{Bilateral simultaneous stimulation}

Stimulation of the entering VIIIth nerve roots of both sides at the same instant by threshold shocks of $.02 \mathrm{msec}$. duration resulted in a movement which was characterized by several flexions of the tail to one side and then to the other. It was not possible to predict which side would be activated first, nor could the subsequent firing order of these cells be

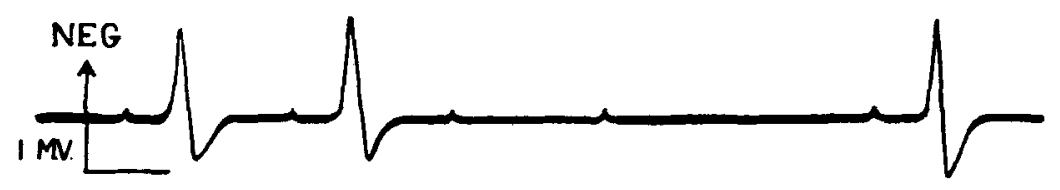

$10 \mathrm{MstC}$

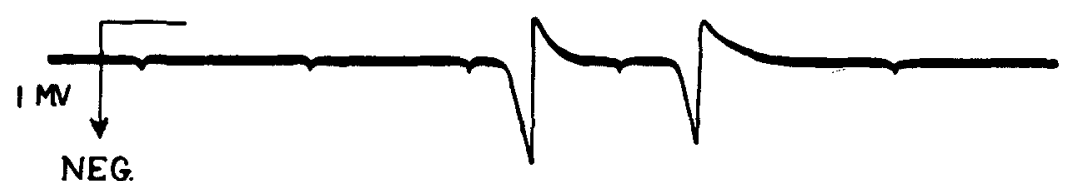

Fig. 7 Effeet of stimuli of short duration (.02 msec.) applied simultaneously to the VIIIth nerve afferents on each side in the curarized fish. Note the reversal of the side of activity as well as the changes in the latent period of the two sides as the recording progresses.
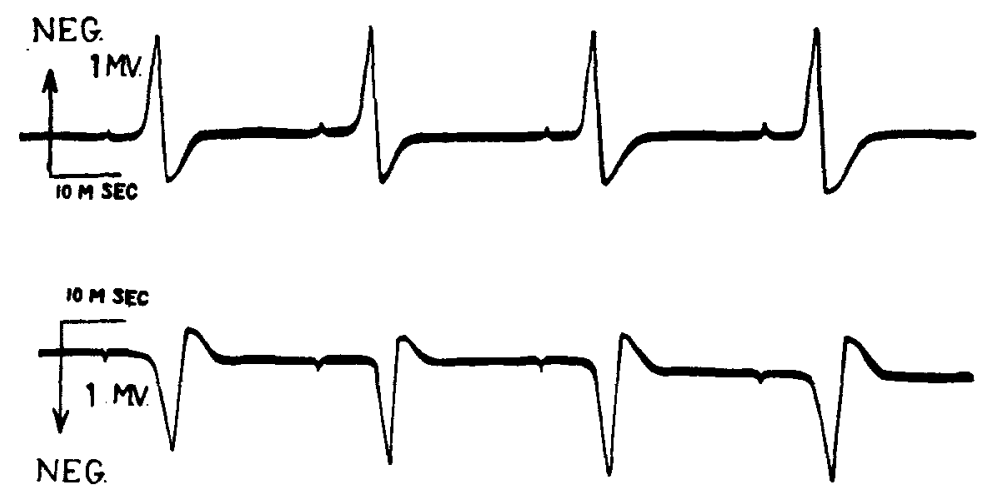

Fig 8. Simultaneous bilateral stimulation of both VIIIth nerve afferent systems with shock of long duration ( 0.1 msec.) in the curarized fish. This resulted in a reciprocal response with one side (upper beam) displaying a latency which agreed with the calculated time while the other had an increased period of delay. 
determined in advance under these conditions. The recordings of this response (fig. 7) clearly demonstrated that both Mauthner's cells were excitable even though only one could be induced to discharge each time both of the afferent root systems were stimulated simultaneously. There was an alteration in the latent period of the two neurons as the result of this procedure, as seen in figure 7 . The second negative potential recorded on the lower beam displays a longer latency than did the first. Apparently, the discharge of one Mauthner's cell was delayed for a short time while it finally attained the proper level of activity for excitation.

Increasing the duration of the bilateral shocks to the VIIIth nerve afferent fibers to $0.1 \mathrm{msec}$. produced a side to side movement of the tail each time the simultaneous stimuli were applied. A typical recording of the evoked potentials from the two Mauthner's axons as seen in figure 8, illustrates a reciprocal type of response. In no instance was it possible to record simultaneously occurring potentials from the homologous axons even though the afferent fibers to these cells were stimulated at the same moment. A difference in the latent period of the two Mauthner's cells is seen in figure 8, where the one side (upper beam) had the expected delay of 6 msec., while that of the other (lower beam) was somewhat longer.

\section{DISCUSSION AND CONCLUSIONS}

This study has shown that there is a definite structural as well as an apparent functional relationship between the VIIIth nerve afferents and the two Mauthner's cells of fishes. It has been found that single decussating VIIIth nerve fibers branch in such a way that some of their collaterals end on the lateral dendrite and perikaryon of the Mauthner's cell on the same side as their origin, and that their terminal collaterals, after forming a part of the axon cap of the Mauthner's cell of the opposite side, make synaptic contact on or near the axon hillock (figs. 1, 2,3). These results support the idea that these cells may function as polar units and that 
a single synaptic neurohumoral agent activates some intraor extracellular substance which could either excite or inhibit, dependent only upon where these endings make contact with the motoneurons.

Various mechanisms for excitatory and inhibitory phenomena based on the concept of polar function have been proposed. In general, the ideas suggested by Gesell ('40b), Gesell et al. ('54) and Eccles et al. ('54) are that the electrical and/or chemical events occurring at the synaptic endings of afferent fibers or their collaterals result in excitation when they contact the dendrites and cell body or inhibits the discharge when they are found on or near the axon hillock. Gesell ('40a,b) assumed that there was a fluctuating potential difference between the dendrites and axon hillock of the neuron which he described as "centrogenic neurocellular current." Gerard ('41) suggested a similar neurocellular mechanism which he called "intrinsic neuronal automaticity." Also, according to Gesell's postulate, the effect of impulses impinging on the dendritic end should increase the potential difference, thus being excitatory, while those impinging on the axon hillock region would have an opposite or inhibitory effect. This idea also demands the active participation of axon collaterals like those reported by Retzlaff ('54b) or of an afferent system such as that described in this report. Another theory recently proposed by Eccles et al. ('54), designated as the Renshaw cell hypothesis, maintains that the hyperpolarization of the axonal end of the motor neuron by the action of the synaptic endings of interneurons (Renshaw cells) results in inhibition. The synaptic effect on the dendritic end of the nerve cell is to hypopolarize it, thus being excitatory in action.

According to the idea presented in this report the divided or branched VIIIth nerve fibers could effect both excitation and inhibition, depending only upon where they make synaptic contact with the two Mauthner's cells (fig. 1). It seems likely that the VIIIth nerve synaptic endings which are found in contact with the opposite ends of each of these two large motor cells function to integrate their activity so that while 
one is discharging, the other is prevented from doing so by an active inhibitory process. This same type of relationship is known to exist in the spinal cord of mammals where branched afferents end on opposite poles of the lower motor neurons. Sherrington ('40) proposed that a single branched afferent could excite the neurons to one muscle group, and at the same time inhibit those to another. He suggested that some intracellular chemical state at the point of synaptic contact determines whether it would excite or inhibit. This idea seems quite reasonable in view of the histological results obtained in this laboratory (Retzlaff, ' $54 \mathrm{~b}$ ). My preparations of central nervous system tissue processed by freeze-dehydration and stained with protargol display distinctly different colorations at the dendritic and axonic poles which indicates a structural and probably a functional polarity.

The observed response of the fish to unilateral stimulation of the VIIIth nerve roots was a powerful flexion of the tail toward the side of the applied stimulus. The movement so produced was a one-to-one stimulus-response type. No doubt, this is the mechanism which when activated results in the reflex escape movement of fishes.

Random stimulation of both VIIIth nerve roots also produced movements which were directly related to the applied stimulus. The evoked potentials recorded from the two Mauthner's axons also were governed by the stimulus sequence. This response demonstrated an active excitation of one of these motor neurons, but there was no way to determine whether the unexcited side was quiescent because of an active inhibition or for some other reason.

The second series of experiments in which bilateral simultaneous stimulation of short duration was applied to the VIIIth nerve roots of both sides, indicated that even though the two Mauthner's cells were excitable it was not possible to induce them to discharge at the same time. This is highly suggestive of an active inhibition of one Mauthner's cell while the other is excited. Stimuli of longer duration applied in the same manner resulted in a reciprocal pattern of 
discharge. Both the observed response and the recorded evoked potentials clearly demonstrate this relationship (fig. $8)$. There was apparently an active excitation of one cell while the other was inhibited for a short time. Gernandt and Thuland ('55) reported a similar reciprocal relationship for the activity of the reticular cells in the medulla of the cat. Alterations in the latent period of the Mauthner's system discharge were evident in all instances. The general rule of this change was that the side which responded first had a latency which agreed with the calculated time while that of the other side consistently displayed an increased time (figs. $6,7,8)$.

It should be noted that when the stimulus was withdrawn from the side which had the normal delay, the other side then displayed a reduced latent period which agreed with the calculated conduction time (fig. 6). The significance of these changes in latency lies in this apparent demonstration of an active inhibitory process rather than mere inactivity.

The concept of monohumoral excitation and inhibition seems well supported by the neurohistological findings described in this report. It seems highly unlikely that the several synaptic endings of a single branched VIIIth nerve afferent could produce chemically different specific excitatory and specific inhibitory humoral agents.

The difference in the responses resulting from the short and the long duration simultaneous bilateral stimulation may be explained by the ratio of neurohumor synthysis to its hydrolysis rate. If a short duration shock produced a quantity of synaptic agent which persisted just long enough to excite one Mauthner's cell and inhibit the other (fig. 7), a longer duration stimulus should cause a greater amount of this agent to be formed. The response then would be the excitation of one cell while the other was inhibited followed by a reversal of the sequence of excitation and inhibition to opposite sides (fig. 8). This reaction is similar to that described by Sherrington ('06) in which spinal reflex after-discharge was found to vary directly with the strength and duration of sensory 
stimulation. The work of Gesell and Hansen ('45) demonstrated a similar relationship between the duration of afterhyperpnea and the duration of carotid nerve stimulation.

Inasmuch as it was never possible under the experimental conditions described in this report to induce both Mauthner's cells to discharge at the same moment it seems that the mechanism of "simultaneous excitation and inhibition" as proposed in an earlier report (Retzlaff, '55) is valid. This idea, based on the structural relationships of the VIIIth nerve afferents and the two Mauthner's cells, was that stimulation of the VIIIth nerve roots of one side should excite the homolateral Mauthner's cell and at the same time inhibit the discharge of the contralateral homologous neuron.

\section{SUMMARY}

1. This investigation has demonstrated the existence of both a structural and a functional relationship between the VIIIth nerve afferent fibers and the two Mauthner's cells in the medulla of fishes.

2. There are single branched VIIIth nerve root fibers which make synaptic contact with the lateral dendrite and perikaryon of the homolateral Mauthner's cell and the axon hillock region of the contralateral cell.

3. Experimental evidence has been obtained which supports the idea that the stimulation of the entering roots of the VIIIth nerve excites the Mauthner's cell on the same side as their entry and at the same time inhibits the discharge of the contralateral cell.

4. It is suggested that monohumoral excitation and inhibition occurred in this case where these single branched afferents ended on opposite poles of the motor neurons.

5. The changes in the latent period of one Mauthner's cell with respect to the other supports the idea that a single, branched axon may both excite and inhibit.

6. The concept of "simultaneous excitation and inhibition" of homologous motor neurons is considered to be valid. 


\section{LITERATURE CITED}

Artïns Kappers, C. U., G. C. Huber and F. C. Crosby 1936 The comparative anatomy of the nervous system of vertebrates including man. New York, N. Y., MacMillan, 2 vol.

Bartelmez, G. W. 1915 Mauthner's cell and nueleus motorius tegmenti. J. Comp. Neur., 25: 87-128.

Bartelmez, G. W., AND N. L. Hoerr 1933 The vestibular club endings in Ameriurus. Evidence on the morphology of the synapse. J. Comp. Neur., 57: 401-428.

Bodian, D. 1937 The structure of the vertebrate synapse. A study of axon endings on Mauthner's cell and the neighboring centers in the goldfish. J. Comp. Neur., 68: 117-159.

1952 Introductory survey of neurons. Cold Spring Harbor Symp. Quant. Biol., 17: 1-13.

BRowN, T. G. 1914 On the nature of the fundamental activity of the nervous centres; together with an analysis of the conditioning of rhythmic activity in progression, and a theory of evolution of function in the nervous system. J. Physiol., 48: 1-48.

Coghill, G. E. $1934 \mathrm{New}$ anatomical relations and probable function of Mauthner's fiber. Psychiat. en Neur. Bladen, 38: 386-391.

Eccles, J. C., P. FATt AND K. Koketsu 1954 Cholinergic and inhibitory synapses in a pathway from motor-axon collaterals to motoneurons. J. Physiol., 126: 524-562.

Gerard, R. 1941 The interaction of neurons. Ohio J. Sci., 41: 160-172.

Gernandr, B. E., And C. A. Thuin 1955 Reciprocal effects upon spinal moto. neurons from stimulation of bulbar reticular formation. J. Physiol., 18: 113-129.

GeselL, R. 1940a Forces driving the respiratory act. Science, 91: 229-233.

$1940 \mathrm{~b}$ A neurophysiological interpretation of the respiratory act. Ergebn. Pliysiol., 43: 477-639.

Gesell, R., AND E. T. HANSEN 1945 Anticholinesterase activity of acid as a biological instrument of nervous integration. Am. J. Physiol., 144 : 126-163.

Gesell, R., C. R. Brassfield and R. H. Lillie 1954 Implementation of electrical energy by paired half-centers as revealed by structure and function. J. Comp. Neur., 101: 331-406.

GRAHAM, H. T., AND J. L. O'LeARY 1941 Fast central fibers in fish. J. Neurophysiol., $4: 224-242$.

Holmgren, B., ANd P. A. Merton 1954 Local feedback control of motoneurons. J. Physiol., 123: 47-48.

Költicker, A. 1891 Zur feiner Anatomie des centralen Nervensystems. Zweiter Beitrag. Ruckenmark, Z. wiss Zool., 51: 1-54.

Lenhossek, M. 1893 Das feinere Bau des Nervensystems im Lichte neuster Forschungen. Berlin, Kornfeld.

RENSHAw, B. 1941 Influences of discharge of mononeurons upon exeitation of neighboring motoneurons. J. Neurophysiol, 4: 167-183. 
Ramón y CaJal, S. 1911 Histologie du systeme nerveux de l'homme et des vertebres. Maloine, Paris, 993 pp.

RETZlafw, E. 1954a Neurohistological evidence for monohumoral excitation and inhibition of the neuron. Fed. Proc., 13: 117-118.

1954b Neurohistological basis for the functioning of paired halfcenters. J. Comp. Neur., 101: 407-446.

1955 Neurophysiological evidence for simultaneous excitation and inhibition of Mauthner's cells of teleost. Fed. Proc., 14: 120-121.

Sherrington, C. S. 1906 The integrative action of the nervous system. Scribners, New York, 433 pp.

1940 Selected writings of Sir Charles Sherrington, Ed. D. DennyBrown. New York, N. Y., Hoeber, $532 \mathrm{pp}$.

Tasaki, I., Hagiwara and A. Watanabe 1954 Action potentials from inside a Mauthner's cell of the eatfish. Jap. J. Physiol., 4: 79-90. 